\title{
THE DYNAMIC MECHANICAL RESPONSE CHARACTERISTICS OF SPINAL CORD TISSUE: A PRELIMINARY REPORT
}

\author{
By E. R. Scull, B.E., A.S.M.B., M.I.E.(Aust.), M.I.B.M.E.(Aust.) \\ Royal Perth Hospital, Bioengineering Division
}

\begin{abstract}
In the absence of an adequate description of the response of spinal cord to dynamic insult, work is in hand to determine the dynamic characteristics of canine spinal cord tissue. In-vitro experimentation is described. A vibration technique using a low amplitude $(0.5 \mathrm{~mm})$, variable frequency $(0-40 \mathrm{~Hz})$ forcing frequency is used to describe the resonant property of the tissue in a supporting environment.

The canine spinal cord is demonstrated to respond as a non-linear, soft, viscoelastic element suceptible in the frequency range $14-22 \mathrm{~Hz}$.
\end{abstract}

Key words: Spinal cord; Dura mater; Ligamentum denticulatum; Biomechanics; Stress (mechanical); Elasticity; Vibration.

\section{Introduction}

THE spinal cord and its composite tissues comprise the sensitive element within the complex dynamic mechanical system of the vertebral column.

With normal habitual movement, the spinal cord is required to accommodate changes in vertebral posture by both movement within the spinal canal and structural deformation.

Breig's observations (1960, 1972) suggest that the spinal canal undergoes an average change of length of between 45 and $75 \mathrm{~mm}$, measured from mid brain to conus medullaris on the dorsal aspect of the cord. Spinal extension is characterised by wavy folding of the relaxed tissues of the cord with straightening and axial tension increasing as the column moves into flexion.

Smith (1956), observing flexion movements of private vertebral column, demonstrated movement of the spinal cord within the canal toward a point of zero relative shift at the $\mathrm{C}_{4}$ level; the maximum movement being $5.9 \mathrm{~mm}$ at the mid-thoracic level. Varying strain of the tissues of the cord was noted, with each segment being stretched in proportion to the movement at the intervertebral joint immediately ventral to it. Tensile forces in the cord were attributed to caudally directed nerve root tethering rather than the overall effect of tension in the filum terminale applied at the caudal extremity.

Reid (I960) confirmed such findings using necropsy preparations. Little relative movement at the $\mathrm{C}_{5}$ level was demonstrated, increasing up to $18 \mathrm{~mm}$ at the level of roots $\mathrm{C} 8$ to $\mathrm{T}_{3}$ for full range extension. An average stretch of the gross spinal cord in this lower cervical region of ro per cent ( 17.6 per cent maximum) with, significantly, little relative movement between the cord and the dura was noted.

Traction forces on the dura from the nerve roots were considered to be transmitted to the cord via the dural sheath and the ligaments denticulata rather than the rootlet structures. 


\section{Quasi-Static Properties}

With normal activity, the energy exchange involved in spinal cord movement and deformation is slow and the cord responds according to its quasi-static properties. While a number of studies (Breig, I960; Galford and McElhaney, 1970; Breig, 1972) provide valuable information on the quasi-static properties of spinal cord tissues the data is limited; pertaining mainly to the properties of dissected meningeal tissue, predominantly the dura.

Tunturi (1977) reports on the mechanical inter-relationship between the structures. of the dura and the spinal cord in the dog. Experimentation demonstrates the cord dura in the dog to be under axial strain (in vivo); tension being transmitted to the dura by the attachments of the dural sheaths of the spinal nerves. Longitudinal strain is progressively imparted to the cord via the denticulate ligaments and dural root sheaths. The degree of tension reported by Tunturi being such that 'the elastic fibres appear to be stretched almost to the limit of their elasticity', has not been verified; our observations indicating that cord tension may vary considerably with animal posture.

Static testing conducted on prepared specimens of canine dura concur with the findings reported in the literature. The dura has been shown to exhibit the two phased stress-strain response typical of collagenous soft tissues (Yamada, 1970, Barbenel et al., 1972; Comninou and Yannas, 1976), with progressive hardening of the elastic modulus in the strain range 9-I7 per cent, to exhibit an elastic modulus in the range $2 \cdot 4-4 \cdot 7 \times 10^{8} \mathrm{~nm}^{-2}$ (Fig. I). This is compared to the apparent

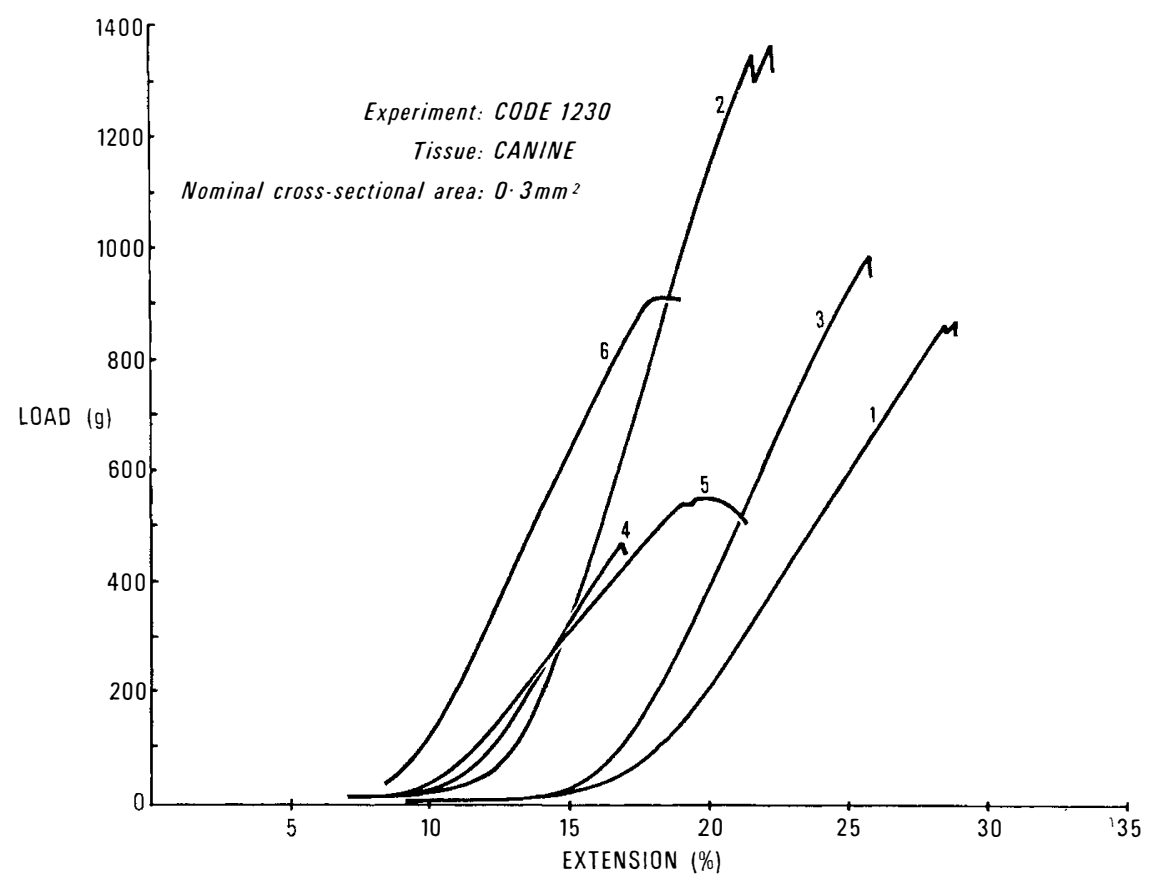

FIG. I

Load-extension test: spinal dura. 
modulus of elasticity for collagen fibre quoted and derived from the literature as $10^{8} \mathrm{~nm}^{-2}, 5 \times 10^{8} \mathrm{~nm}^{-2}$ and $\mathrm{II} \cdot 5 \times 10^{9} \mathrm{~nm}^{-2}$ (Tunturi, I977; Barbenel et al., 1972; Haut and Little, 1972; respectively). Variation in the histological structure of the dura around the canine spinal cord is evident with marked thickening of the dura along the dorsal and ventral surfaces.

The significance of structural variations around the cord and along its length, as they affect the physical characteristics of the dura, are under investigation.

\section{Dynamic Properties}

As the vertebral column becomes involved in dynamic activities, the energy exchanges between the column and the spinal cord increase. More particularly, the energy exchanges within the cord complex vary; dominated now by its dynamic response characteristic rather than the static property of the cord. There is no comprehensive study concerning the rheologic properties of the spinal cord which details its response to high speed non-invasive trauma. Typical of such trauma is axial impact, whole body vibration and the cervical hyper-extension/flexion injury. The progressive pathologies of the spinal cord and its support tissues, which manifest as a clinically observable symptom, are conceived from the injury contracted in the few milliseconds of such a dynamic response. If knowledge of the aetiology of non-invasive injury of the cord and related trauma is to develop, it must depend on a reliable model which demonstrates the dynamic physical properties of the cord complex and its tissues.

\section{Materials and Methods}

A test programme has been developed to ascertain the dynamic properties of spinal cord tissue with emphasis being placed on the need for the experimental model to be analogous to the operation of the cord, in vivo.

Dissections of canine spinal cord have been carried out to ascertain the reliability of the preparation as being anatomically similar to human spinal cord. The ligamenta denticulata of the canine cord are observed to be less developed than those at equivalent levels in the human cord, possibly due to postural effects and differences in the surface vascularity of the canine and human cord were noted (Fig. 2).

The former is considered to be a possible source of difference between canine and human preparations in terms of their physical responses.

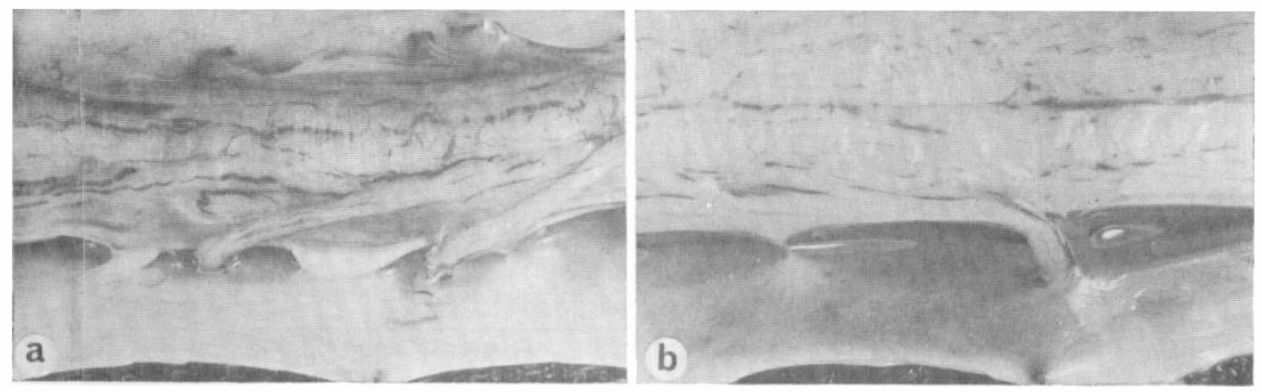

FIG. 2

Comparative anatomy of ligamentum denticulata of spinal cord; (a) human spinal cord (top), (b) canine spinal cord. 
Specimens are dissected for testing and held at $2{ }^{\circ} \mathrm{C}$ in Ringers solution. Routine testing is carried out at between 3 and 4 hours post mortem. Prepared blocks of spinal cord are mounted in grips which both grip the meningeal tissues and provide a solid interface against the exposed ends of the neural column. Care is taken to avoid unwarranted handling of this tissue, pre-stressing and drying during the preparation procedure.

The block of spinal cord composite is subjected to a forced axial vibration, in vitro, using an input vibration of amplitude $0.5 \mathrm{~mm} \mathrm{p}-\mathrm{p}$ over the frequency range I to $40 \mathrm{~Hz}$. The frequency range has been adopted initially to include the natural frequency for dural tissue, reported by Galford and McElhaney as $2 \mathrm{I} \mathrm{Hz}$. The amplitude gain and phase difference for the vibrations across the block of tissue are derived from LVDT displacement transducers. With a carrier frequency of $2.5 \mathrm{kHz}$, transducer frequency response is considered reliable up to approximately $200 \mathrm{~Hz}$.

Initial pilot studies have been upgraded by the addition of an air bearing system to carry the lower grip and the output LVDT core, to maintain alignment, to prevent the friction effects of transducer contact and to reduce the stimulation of transverse vibration in the specimen (Fig. 3). The introduction of experimental refinements has allowed demonstration of the second harmonic response, expected but not seen in the pilot study. Forcing mass, suspended on the freely vibrating end of the cord can be varied and the preparation is maintained in a chamber saturated by a nebulised fog of water during the experiment. Fluid losses from the suspended cord during a multiple experiment lasting approximately two hours, with continual chamber saturation, has been estimated at less than 5 per cent.

Pilot experiments, requiring runs of both increasing and decreasing frequency over the range $0-40 \mathrm{~Hz}$, involved up to three hours experimentation. It was considered that changes within the tissue prejudiced tissue responses during the course of such an experiment.

Manual observation and recording of displacement signals from a dual channel oscilloscope, frequency and phase meter data has been replaced by real time data

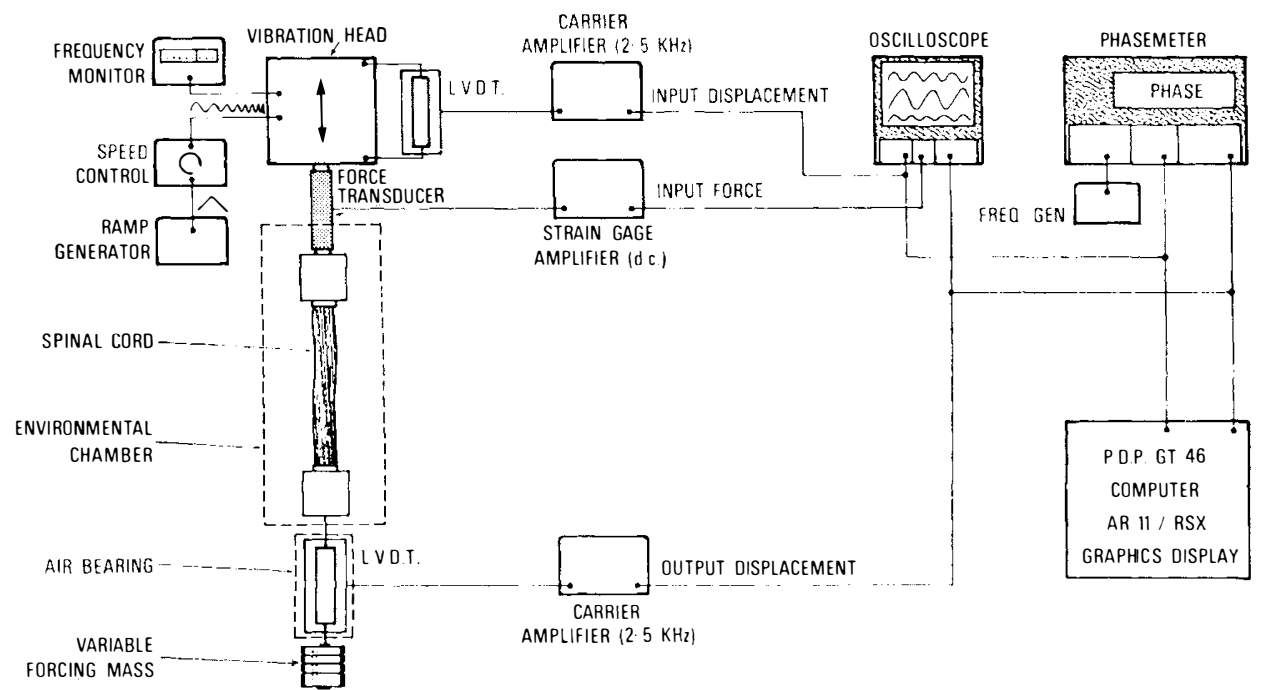

FIG. 3

Vibration rig for testing dynamic spinal cord properties. 
capture and analysis using a PDP I I/34 computer. Blocks of data of I024 samples at a sampling rate of $6 \mathrm{msec}$, are collected from both input and output displacement signals. The forcing frequency can be changed manually or ramped over the range $0-40-0 \mathrm{~Hz}$ at a variable rate. Periods for the ramp of 1000 seconds are typical, reducing experimental time to 16 minutes or less. The data is analysed by Fast Fourier transform techniques (with the option for discrete Fourier analysis), eliciting data on amplitude gain and phase difference for frequency increments of approximately $0.4 \mathrm{~Hz}$ over the frequency range. Each frequency run is preceded by a free vibration experiment using a stepped input of $0.5 \mathrm{~mm}$, to estimate the damped natural frequency of the cord preparation under test and its damping co-efficient.

Parameters unrelated to fundamental tissue properties, such as tissue length and forcing mass, effect both the free and forced vibrations of the preparation. Tissue response characteristics excluding the effects of such factors are compared on plots of amplitude gain and phase difference against normalised frequency; the latter being the ratio of frequency (W) to the undamped natural frequency (Wn) for that block of tissue under test.

\section{Results}

The canine spinal cord has been demonstrated to behave as a dynamic element with a non-linear, soft, viscoelastic characteristic. Linear elements when subjected to an increasing forced frequency, will vibrate with an amplitude gain of one (i.e. the input following the output) at low frequency, the amplitude gain building up to a maximum as the element resonates at its natural frequency. The size of the amplitude gain at resonance depends on the degree of viscous damping in the element.

With further frequency increase the amplitude gain decreases to values less than one at high frequency. If the elastic element changes its elastic modulus

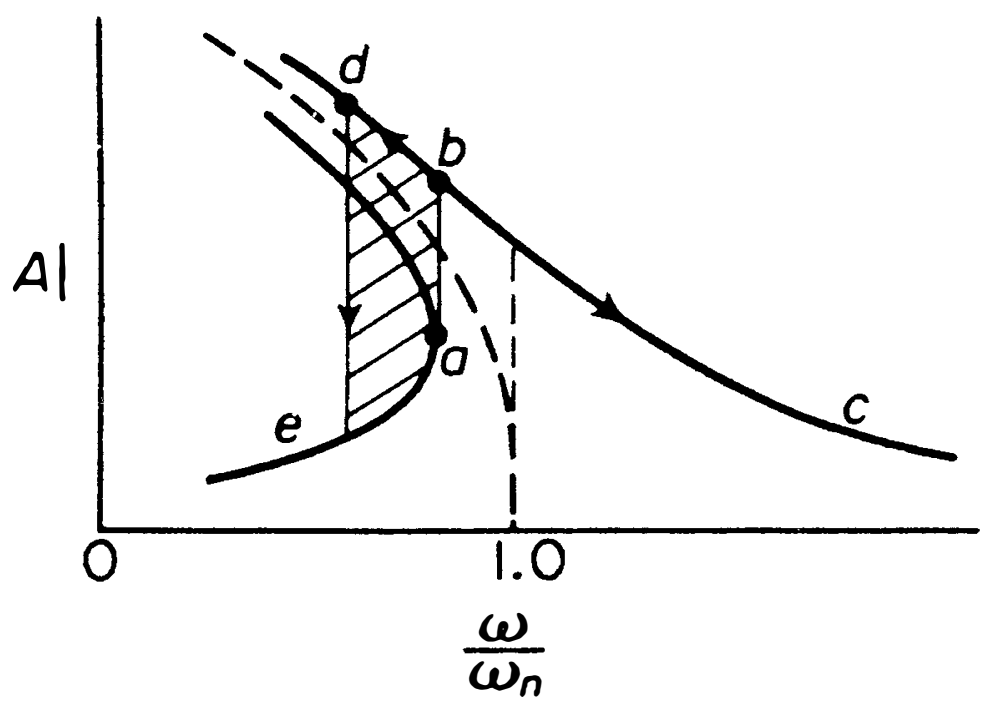

FIG. 4

'Soft' sprint resonant characteristic. 
during the process of being strained, it is non-linear and the response described varies. If the elastic element stiffens with strain, the element is termed a 'hard' spring and, conversely, if the element softens (i.e. it reduces its modulus of elasticity with strain) it is a 'soft' spring. It is noted that quasi-static testing shows dural tissue to harden with strain and consequently a non-linear hard spring characteristic was expected in the dynamic test programme. The reverse has been demonstrated and is supported. As such, the amplitude gain-frequency curve shows a resonant characteristic which 'droops' back toward the low frequency zone (Fig. 4).

The importance of such a characteristic lies in the direction of the 'droop' (i.e. the soft nature of the curve) and the fact that as the input or forcing frequency approaches the nose of the curve (point a), the output vibration goes critical and the amplitude gain jumps instantaneously to near resonant values. The critical jump ( $a$ to $b$ ) occurs at values below the natural frequency and requires only a low energy input, i.e. few cycles of low amplitude, to produce the critical response. Critical frequencies of between 16 and $18 \mathrm{~Hz}$ are typical for cord samples of $40 \mathrm{~mm}$ length. Such frequencies correspond to normalised values of between 0.7 and 0.9 (Fig. 5).

A second harmonic, also demonstrating a soft spring characteristic is evident at high frequencies (Fig. 6). The critical point for second harmonic response is approximately twice that of the first harmonic, being typically $35-40 \mathrm{~Hz}$.

The response characteristic demonstrated has been replicated in multiple testing on single specimens (Fig. 7), indicating that only minor strain history is impressed on the specimen during the course of an experiment. Testing of number of specimens from varying levels of the cord, when plotted on a normalised frequency axis $(\mathrm{W} / \mathrm{wn})$, illustrates a consistent dynamic response characteristic (Fig. 8).

Some success has been achieved in synthesizing the nature of the response by using a modified classical dynamics method based on Duffings equation. The envelope curve generated by the equation with zero damping is shown in Fig. 8 .

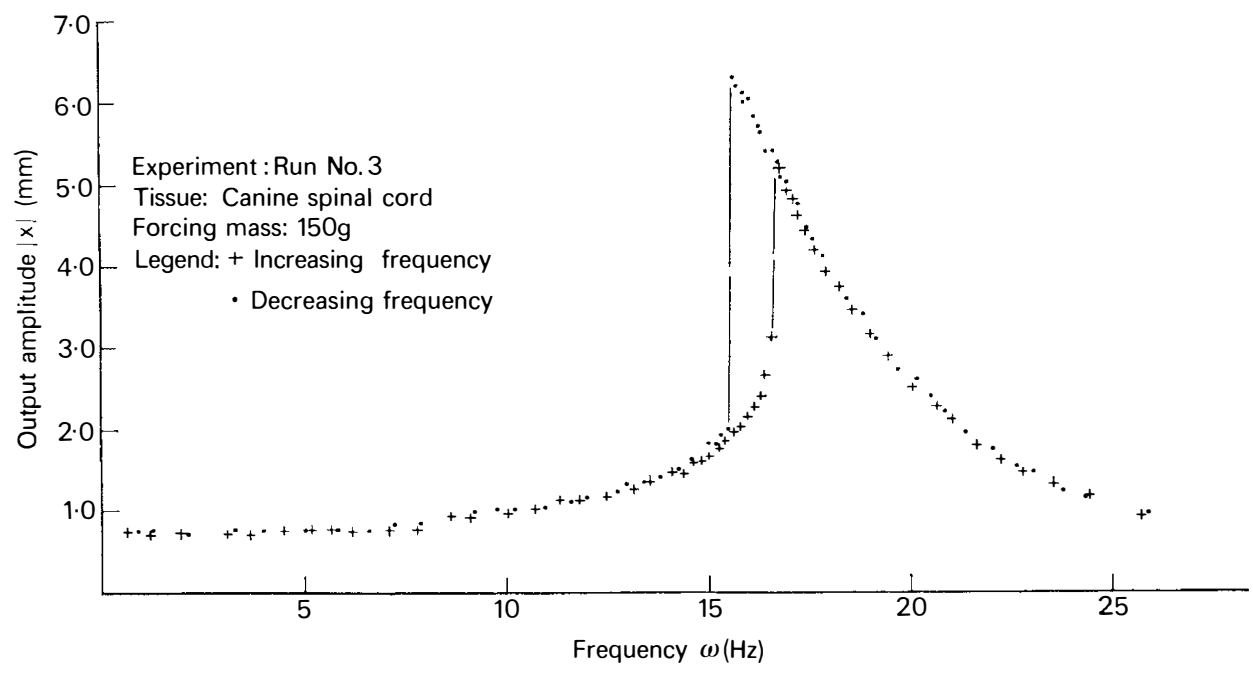

FIG. 5

Spinal cord vibration test: pilot study. 

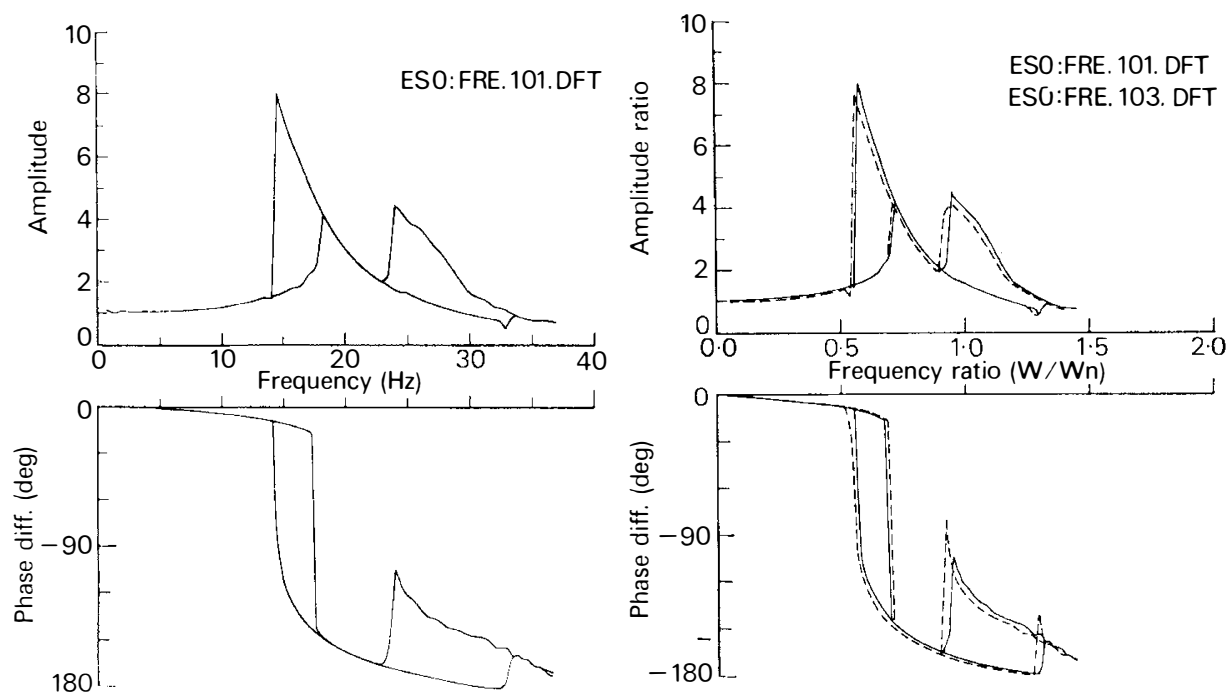

(6)

(7)

FIG. 6

Spinal cord vibration test including second harmonic response.

FIG. 7

Spinal cord vibration test: replicate test on single specimen.

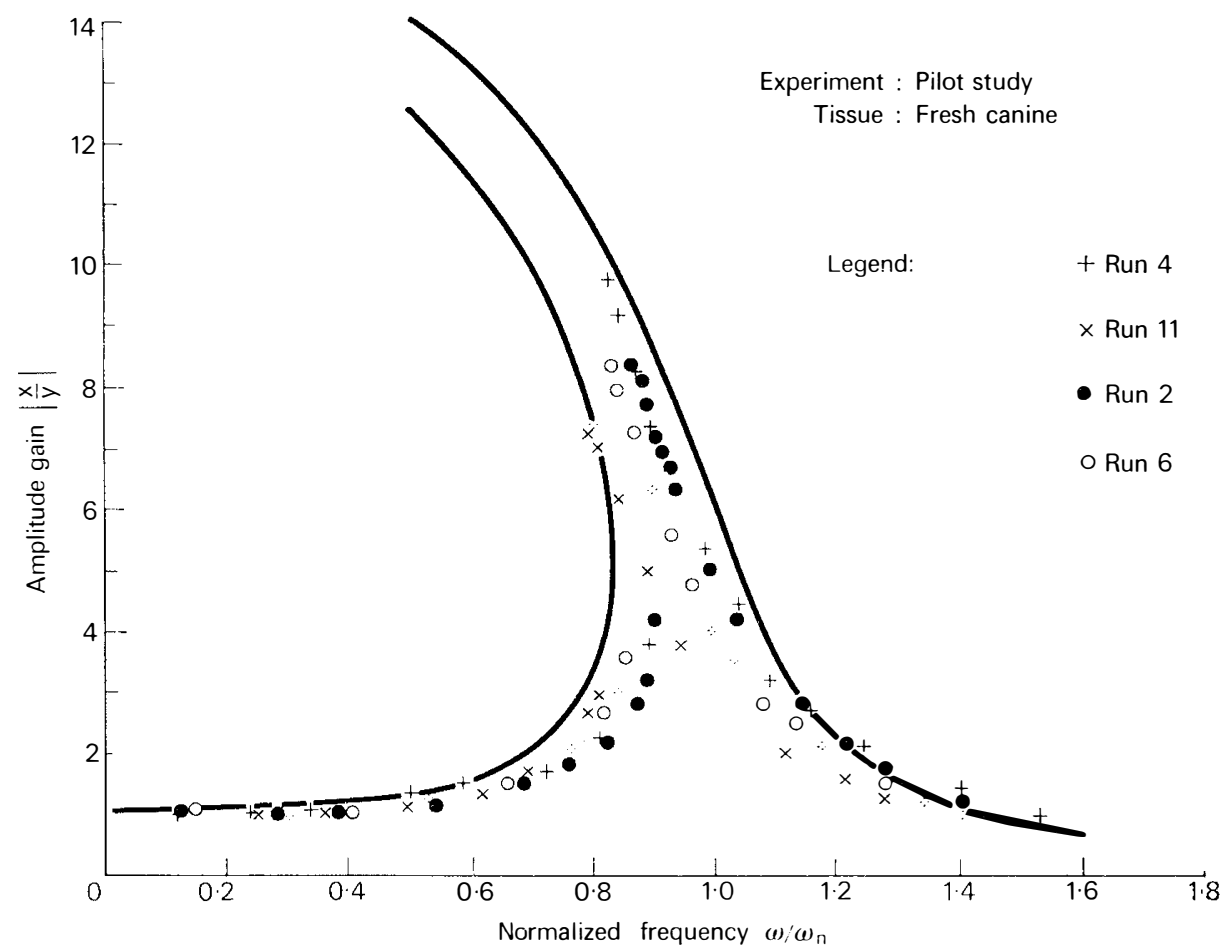

FIG. 8

Approximation of normalized spinal cord data to Duffings equation: multiple testing. 


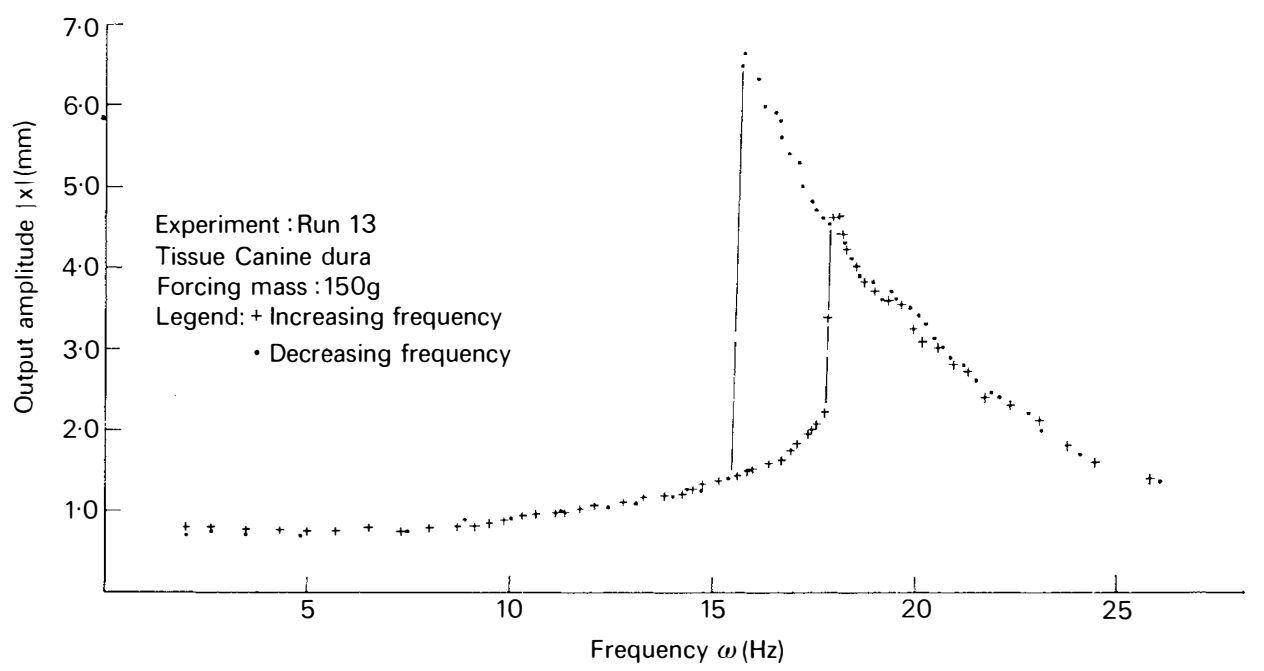

FIG. 9

Spinal cord vibration test: pilot study (dura only).

Testing carried out on the tissues of the meningeal sheath alone shows a similar response characteristic suggesting that the meninges, and in particular the dura, dominate the response characteristic of the total cord (Fig. 9).

\section{Discussion}

Considerable work is required to relate the findings reported for canine spinal cord, in vitro, to the response of human spinal cord restrained within the complex of the spinal canal. The effects of multi-level tethering at the dural sheaths, the damping effects of the c.s.f., etc., are all pertinent. If such work is judged significant, then it can only continue based on a clear understanding of the characteristics of each of the elements in the complex interactive system.

Quasi-static testing has verified the visco-elastic nature of spinal cord meningeal tissue and confirmed the elastic hardening of the tissue at strain levels above approximately 9 per cent. Dynamic testing using a resonant vibration technique demonstrates the spinal cord to respond to dynamic stimulus as a non-linear, SOFT, visco-elastic element. Natural frequencies of composite blocks of canine spinal cord are typically $20-25 \mathrm{~Hz}$ with critical frequencies at approximately 0.7 to 0.9 of the natural frequency.

The static and dynamic models are contradictory; the reasons for the dichotomy requiring investigation. It is noted however, that the static hard response is a macro effect requiring considerable tissue strain (9-I7 per cent). Critical response during dynamic testing occurs with strains propagated in the tissue being in the order of I-2 per cent.

Dynamic strains are overlayed on the static strains due to mass effects of approximately $2 \cdot 5-3$ per cent. As such the dynamic strains, before the element turns critical, are below the degree of tissue strain required for the hardening effect.

Improved accuracy in the investigation of the nature of the quasi-static stress-strain curve at low strains (up to approximately 3 per cent) is required to 
ascertain the nature of the curve in this region. A curve of decreasing elastic modulus in this region would support the dynamic model described and, while testing to date has been masked by poor load sensitivity, a programme is current to test this hypothesis.

It is proposed that the non-linear soft spring characteristic renders spinal cord tissue to be innately susceptible to impacts and low energy forcing vibrations in the frequency range $14-22 \mathrm{~Hz}$.

Experimentation and modelling of the movement of the head and neck in impact decelerations (Mertz and Patrick, 1967; Tarriere and Sapin, 1969; Melvin et al., 1971; Ewing and Thomas, 1973; Prasad et al., 1975; Ewing et al., 1976), demonstrates severe angulation of the head relative to the torso, with up to I-2 cycles of vibration at frequencies in the range $3-22 \mathrm{~Hz}$. Hyper-flexion/extension responses, producing the cord tensions and movement postulated by Reid and Smith at such frequencies, would feasibly present the spinal cord with a forcing input in the critical region demonstrated. Studies on whole body vibration (Parks, I962; von Gierke and Coerman, I963), relate the level of tolerance to vibration intensity to the frequency at which the body component resonates. Peripheral symptoms were noted at the frequencies related to head and spinal resonances, the resonant frequency of the head relative to the shoulder girdle being $30 \mathrm{~Hz}$.

More efficient experimentation has opened up the possibilities of checking effects such as strain history, post mortem changes, etc., and depending on the results obtained allows extension of the experimental programme to include human post mortem tissue.

If, despite the modifying effects of anatomical constraints in vivo the cord retains its fundamental resonant characteristic, new areas of speculation are justified. For example, a transient entrapment or tethering of the cord during trauma would feasibly produce the quite different progressive pathologies encountered in clincial practice, depending on whether the cord is in a tension or recovery phase during the incidence.

High strain rates at such points of tethering and anatomical constraint may cause severe local stress and, as such, could be a potential cause of cellular cavitation a possible precursor of progressive hydro-syrinx pathologies.

It seems inevitable that the laboratory work reported must be qualified by in vivo testing to check the causal effects on vascular supply, the physiological performance of neural tissue, etc. The prospect is formidable but nevertheless occupies a real place in future planning for this work.

\section{SUMMARY}

The spinal cord is part of a complex dynamic mechanical system. Normal activity subjects the cord to slow energy exchanges under which it responds according to its quasi-static properties; properties described in the literature and noted by clinical examination. Energy exchange increases rapidly with active exercise, body vibration and non-invasive trauma.

In the absence of an adequate description of the response of spinal cord to dynamic insult, work is in hand to determine the dynamic characteristics of canine spinal cord tissue. In vitro experimentation is described. A vibration technique using a low amplitude $(0.5 \mathrm{~mm})$, variable frequency $(0-40 \mathrm{~Hz})$ forcing vibration is used to describe the resonant property of the tissue in a supporting environment.

The canine spinal cord is demonstrated to respond as a non-linear soft 
visco-elastic element; with early work indicating that the response characteristic is dominated by the property of the dura. It is proposed that the non-linear soft spring characteristic renders spinal cord tissue innately susceptible to low energy inputs such as impact, cervical whiplash and forced axial vibration in the frequency range $14-22 \mathrm{~Hz}$.

Acknowledgements. The support of the Royal Perth Hospital Research Foundation, the Engineering Faculty of the University of Western Australia and the valued assistance of my colleagues is gratefully acknowledged.

\section{RÉSUMÉ}

Le cordon médullaire fait partie d'un système mécanique dynamique complexe. Une activité normale soumet le cordon à des échanges d'énergie lents sous lequels il répond selon ses propriétés quasi-statiques; propriétés qui sont décrites dans les textes et observées par examen clinique. L'échange d'énergie augmente rapidement avec exercice actif, vibrations du corps et trauma non-envahissant.

A défaut d'une description suffisante de la réaction du cordon médullaire à une lésion dynamique, des recherches sont en cours pour déterminer les caractéristiques dynamiques du tissu du cordon médullaire canin. L'expérimentation in-vitro est décrite. Une vibration technique employant une basse amplitude $(0.5 \mathrm{~mm})$, une fréquence variable $(0-40 \mathrm{~Hz})$ forcant vibration est employée pour décrire la propriété résonnante du tissu dans un milieu soutenant.

On démontre que le cordon médullaire canin réagit en élément non-linéaire mou visco-elastique; avec les premiers travaux indiquant que la réponse caractéristique est dominée par la propriété de la dura. On propose que la caractéristique non-linéaire molle élastique rend le tissu du cordon médullaire susceptible d'une manière innée à des sources de basse énergie telles que choc, traumatisme cervical par projection (whiplash) et vibration axiale forcée d'un champ de fréquence de $14-22 \mathrm{~Hz}$.

\section{ZUSAMMENFASSUNG}

Das Rückenmark ist Teil eines komplizierten dynamisch-physikalischen Systems. Während normaler Tätigkeit ist das Rückenmark langsamen Energieaustausch unterworfen, unter welchem es gemäss seinen quasi-statischen Eigenschaften, die in der Literatur beschrieben und durch klinische Prüfung bekannt gemacht sind, reagiert. Energieaustausch steigt schnell mit lebhafter Tätigkeit, Körperschwingung und undurchdringliches Trauma.

Da eine hinreichende Beschreibung der Reaktion des Rückenmarkes auf dynamischen Schock nicht vorhanden ist, wird jetzt an der Bestimmung der dynamischen Eigenschaften von Hunderückenmarkgewebe gearbeitet. In-vitro Verusche sind beschrieben. Ein Schwingungsverfahren mit einer niedrigen Schwingungsweite $(0.5 \mathrm{~mm})$, veränderlicher Frequenz $(0-40 \mathrm{~Hz})$ forcierender Schwingung wird benutzt die resonante Eigenschaft des Gewebes in einer unterstützter Umgebung zu beschreiben.

Es wird gezeigt, dass das Hunderückengewebe wie ein nichtlineares weiches viskoselastisches element reagiert. Anfangsergebnisse deuten an, dass die Reaktionseigenschaften von der Eigenschaft der dominiert werden. Es wird vorgeschlagen, dass die nichtlineare weiche elastische Eigenschaft den Rückenmarkgewebe von Natur aus empfindlich macht genen niedrige Energieeingaben wie Zusammenstoss, Nacken-Schleudertrauma und forcierte Axialschwingung in der Frequenzbereich von $14-22 \mathrm{~Hz}$.

\section{REFERENCES}

Barbenel, J. C., Evans, J. H. \& Finlay, J. B. (I972). Stress-strain-time relations of soft connective tissues. Perspectives in Biomedical Engineering, ed. Kenedi, 165-172.

Breig, A. (I960). Biomechanics of the central nervous system. Almqvist and Wiksell, Stockholm.

BREIG, A. (I972). The therapeutic possibilities of surgical bio-engineering in incomplete spinal cord lesions. Paraplegia, 9, I73-182. 
Comninov, M. \& Yannas, I. V. (1976). Dependence of stress-strain non-linearity of connective tissues on the geometry of collagen fibres. F. Biomechanics, 9, 427.

Ewing, C. L. \& ThOMAs, D. J. (I973). Torque versus angular displacement response of human head to $-G x$ impact acceleration. SAE Paper 730976. Proc. 17th Stapp. Car Crash Conf. November, 1973, 309-342.

Ewing, C. L. et al. (1976). The effect of duration, rate of onset and peak sled acceleration on the dynamic response of the human head and neck. SAE Paper 760800, Proc. 20th Stapp Car Crash Conf., October, I976, 3-4I.

GALFORD, J. E. \& McElHANEY, J. H. (I970). A viscoelastic study of scalp, brain and dura. f. Biomechanics, 3, II I-I 24 .

Haut, R. C. \& Little, R. W. (1972). A constitutive equation for collagen fibres. $\mathcal{F}$. Biomech., 5, 423-430.

Melvin, J. W. et al. (I97I). Deployable head restraints-a feasibility study. SAE Paper 710853. Procs. I 5th Stapp Car Crash Conf., November, I97I, I 58-189.

Mertz, H. J. \& PAtrick, L. M. (I967). Investigation of the kinematics and kinetics of whiplash. SAE Paper 670919, Proc. IIth Stapp. Car Crash Conf. October, I967, 267-3I7.

PARKs, R. L. (I962). Defining human reaction to whole body vibration. Human Factors, 4, 305-3I4.

Prasad, P. et al. (1975). Dynamic response of the spine during $+\mathrm{Gx}$ accelaration. SAE Paper 75II72. Procs., I9th Stapp car crash Conf., November, I975, 869-897.

REID, J. D. (1960). Effects of flexion-extension movements of the head and spine upon the spinal cord and nerve roots. F. Neural. Neurosurg. and Psych., 23, 214-221.

SMIth, C. G. (1956). Changes in length and position of the segments of the spinal cord with changes in posture in the monkey. Radiology, 66, 259-266.

TARRIERE, C. \& SAPIN, C. (I969). Biokinetic study of the head to thorax linkage. SAE paper 690315, Proc. 13th Stapp. Car Crash Conf. December, 1969, 369-380.

Tunturi, A. R. (1977). Elasticity of the spinal cord dura in the dog. $\mathcal{F}$. Neurosurg., 47, 39I-396.

von Gierke, H. E. \& Coermann, R. R. (1963). The biodynamics of human response to vibration and impact. Incl. Med and Surg., 52, 30-32.

Yamada, H. \& Evans, F. G. (I970) Strength of biological materials. Williams \& Wilkins Co., Baltimore. 